Florida International University FIU Digital Commons

11-13-1992

\title{
Precompetition dietary practices of competitive male and female bodybuilders
}

Janet Bond Brill

Florida International University

DOI: $10.25148 /$ etd.FI14051838

Follow this and additional works at: https://digitalcommons.fiu.edu/etd

Part of the Dietetics and Clinical Nutrition Commons

\section{Recommended Citation}

Brill, Janet Bond, "Precompetition dietary practices of competitive male and female bodybuilders" (1992). FIU Electronic Theses and Dissertations. 1809.

https://digitalcommons.fiu.edu/etd/1809

This work is brought to you for free and open access by the University Graduate School at FIU Digital Commons. It has been accepted for inclusion in FIU Electronic Theses and Dissertations by an authorized administrator of FIU Digital Commons. For more information, please contact dcc@fiu.edu. 
Subject: Re: FIU's digitization of your Dietetics and Nutrition thesis

Date: Friday, June 5, 2015 at 4:06:48 PM Eastern Daylight Time

From: Janet Brill

To: $\quad$ Rebecca Bakker

Sure, fine with me.

Sent from my iPhone, please excuse typos.

On Jun 5, 2015, at 1:05 PM, Rebecca Bakker<rbakker@fiu.edu> wrote:

Dear Dr. Brill:

Florida International University's Digital Collections Center is offering a new service to graduate alumni: digitization of your theses and dissertations. This new service will enable your scholarship to be preserved and shared for research and educational purposes, at no cost to you, and will be made available through FIU's Electronic Theses and Dissertations on our Digital Commons website. The FIU Digital Commons is a digital repository for capturing, archiving and disseminating the research, creative and scholarly output of the Florida International University community. Our graduates' theses and dissertations are a valuable part of FIU's scholarship, and are a frequently accessed part of our digital collections.

Your 1992 thesis titled Precompetition dietary practices of competitive male and female bodybuilders is in the process of being digitized for preservation and so that it may be made available in Digital Commons. At your earliest convenience, please reply to this email providing your authorization for your thesis to be made available online. Please be advised that FIU may make your thesis available online if we do not hear back from you within 90 days. If at any point you wish to have your thesis taken offline, please contact us

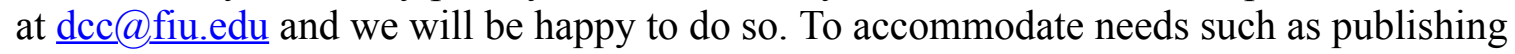
contracts and patents, FIU can also add a period of embargo, or alternatively provide only an excerpt of your thesis.

If you have any questions or concerns, please do not hesitate to contact me. Thank you for your contributions to Florida International University!

Sincerely,

Rebecca Bakker

Digital Project Coordinator

Digital Collections Center

Green Library - GL 825, MMC Campus

Florida International University

Reference \# FI14051838 